Louise Roy MD FRCPC, Daniel Vischoff MD, Josée Lavoie MD FRCPC

\title{
Epidural blood patch in a seven-year-old child
}

We present an unusual case of postoperative headache in a child afier an epidural block. A seven-year-old girl (ASA 1) was scheduled to undergo a urological procedure under general anaesthesia combined with an epidural technique for intra- and postoperative analgesia. Although there was no evidence of dural puncture when the block was performed, the patient developed a headache postoperatively. The headache, which was accompanied by neck pain, appeared in the sitting or standing position and was relieved by decubitus. According to the mother, her child had never complained of those symptoms in the past. After independent evaluation by an anaesthetist and a neurologist, a postdural puncture headache (PDPH) was considered the most likely diagnosis. As oral analgesics failed to provide relief, an epidural blood patch (EBP) using $10 \mathrm{ml}$ autologous blood was performed under light sedation. This was followed by resolution of the symptoms. Epidural injections of opioids and local anaesthetics are becoming increasingly popular for pain management in children. This implies that there may be an increasing number of unintentional dural punctures that may result in more PDPHs in children. Epidural blood patches are effective in treating PDPHs in adults but their use has been reported very rarely in children. Resolution of the patient's symptoms following EBP supported the diagnosis while illustrating that EBP can be useful in the treatment of PDPH in children.

Nous rapportons un cas inhabituel de céphalées survenues en période postopératoire chez une enfant après une technique péridurale. Une patiente de sept ans a été admise pour subir une chirurgie urologique sous anesthésie générale combinée à une péridurale. Au cours de la période postopératoire, la patiente a développé une céphalée sans qu'll n'y ait eu aucune

\section{Key words}

ANAESTHESIA: paediatric;

ANAESTHETIC TECHNIQUES: regional, epidural; COMPLICATIONS: headache.

From the Department of Anaesthesia, Hôpital Sainte-Justine and University of Montréal, Montréal, Canada.

Address correspondence to: Dr. Louise Roy, Department of Anaesthesia, Hôpital Sainte-Justine, 3175, Ch. Côte Ste-

Catherine, Montréal, Québec, Canada H3T IC5.

Accepted for publication 22nd February, 1995. évidence de ponction de dure-mère lors de la technique péridurale. Les céphalées, associées à des cervicalgies, étaient de nature positionnelle: aggravees par la position verticale et soulagées par le décubitus. Selon la mère, sa fille ne se serait jamais plainte de céphalées dans le passé. Une anesthésiste et un neurologue, après avoir chacun évalué la patiente de façon indépendante, ont retenu la céphalée past-ponction de dure-mère (CPPDM) comme étant le diagnostic le plus probable. Devant l'inefficacité des analgésiques oraux, une injection péridurale de sang autologue (IPSA) de $10 \mathrm{ml}$ a été pratiquée sous sédation légère. Par la suite, la patiente a noté la disparition de ses symptômes. Liutilisation d'anesthésiques locaux et de narcotiques par voie péridurale pour le contrôle de la douleur connaît une popularité croissante en pédiatrie. Ceci implique une augmentation des ponctions de dure-mère accidentelles et la possibilité d'une incidence accrue de CPPDM dans ce groupe d'âge. L'efficacité de l'IPSA dans le traitement des CPPDM a été bien démontrée chez l'adulte mais n'a été rapportée que très rarement chez l'enfant. La résolution des symptômes de cette patiente suite à I'TPSA a confirmé notre diagnostic en plus d'illustrer son utilité dans le traitement de la CPPDM dans la population pédiatrique.

Although postdural puncture headache (PDPH) is a well known complication of spinal and epidural techniques in adults, its occurrence in children is rare. ${ }^{1,2}$ The incidence of PDPH in adults varies. Dittmann et al. ${ }^{3}$ observed an incidence of $1.37 \%$ with the use of a 29 -gauge needle while Flaatten et al. ${ }^{4}$ found a $33 \%$ incidence of PDPH in young adults after spinal anaesthesia performed with a 25 -gauge needle. A rate as high as $80 \%$ has been reported in obstetrical patients after unintentional dural puncture. ${ }^{5}$ In the paediatric population, few cases have been reported. Commenting on hundreds of lumbar punctures (LP) done in children at his institution, Fernbach stated that "headache virtually never follows lumbar puncture in children, particularly those under ten years of age. ${ }^{76}$ Plaut performed 100 diagnostic LPs and noted the occurrence of two headaches after the procedure although no details were given on the characteristics of those headaches. ${ }^{\text {? }}$

Treatment of PDPH with epidural blood patch (EBP) was first described by Gormley in $1960 .{ }^{8}$ Its efficacy in 
the adult population is rated to be between 90 to $95 \% .^{9}$ Its use in children has been very rarely reported. ${ }^{10-12}$

We describe the case of a seven-year-old child who developed positional headache following an urological procedure under combined general and epidural anaesthesia. The patient was treated successfully with an EBP.

\section{Case report}

A seven-year-old girl $(23 \mathrm{~kg})$ with a history of recurrent urinary tract infection secondary to ureterovesical reflux was admitted for bilateral ureteroneocystostomy. Otherwise, the patient's past medical history was negative (ASA 1). She was fasted overnight except for clear fluids which were allowed until three hours preoperatively. No premedication was given before being taken to the operating room. Monitoring consisted of a 3-lead ECG, noninvasive blood pressure, pulse oximeter, capnograph, precordial stethoscope and nasopharyngeal temperature probe. Anaesthesia was induced by inhalation with a mixture of nitrous oxide (70\%), oxygen (30\%), and halothane (up to $3 \%$ ). A peripheral $i v$ catheter was inserted and atropine $\left(0.01 \mathrm{mg} \cdot \mathrm{kg}^{-1}\right)$ injected. The patient's trachea was then intubated orally and the endotracheal tube was secured. She was then positioned in the left lateral decubitus position to perform lumbar epidural block. A 17-gauge Tuohy needle was inserted at the $\mathrm{L}_{3}-\mathrm{L}_{4}$ interspace using a loss of resistance technique with air. The epidural space was easily identified on the first attempt and a 19-gauge Portex catheter with side holes was threaded in $3 \mathrm{~cm}$ without encountering any resistance.

Anaesthesia was maintained with $\mathrm{N}_{2} \mathrm{O} / \mathrm{O}_{2}(60 \% / 40 \%)$, halothane $(0.8-1 \%)$. Bupivacaine $0.125 \%$ was given by $2 \mathrm{ml}$ increments through the catheter up to a total volume of $8 \mathrm{ml}(10 \mathrm{mg})$ after the initial injection. Fentanyl $(25$ $\mu \mathrm{g}$ ) diluted with normal saline to $2 \mathrm{ml}$ was also administered epidurally. Attempted aspiration through the epidural catheter before each injection did not produce any fluid. Blood pressure and heart rate were stable throughout the procedure. At the end of surgery, the patient was transferred to the recovery room where the trachea was extubated after $30 \mathrm{~min}$. Bupivacaine $0.125 \%(8 \mathrm{ml})$ was injected before the epidural catheter was removed (two hours after the first dose). Again, aspiration through the catheter was negative for fluid. Throughout her stay in the recovery room, the patient was comfortable and could move her legs easily on demand.

In the early postoperative course, there were several episodes of nausea and vomiting that persisted until the following morning but the mother commented that her child was prone to nausea and vomiting.

Two days after surgery, the child spontaneously complained of headaches accompanied by neck pain. The intensity of these headaches was increased when the child attempted sitting up or getting out of bed. She said she preferred lying down since her headaches disappeared in that position. At the time, the patient complained only of moderate discomfort at the site of the incision that was easily relieved by codeine $(15 \mathrm{mg})$ po. She was assessed by an anaesthetist and a neurologist on the third postoperative day. The two evaluations were made independently. Apart from the occurrence of a headache and neck pain while assuming the erect position, the neurological examination was normal. The patient's body temperature remained within the normal range. Based on the clinical signs, a diagnosis of PDPH was made. On postoperative day 4 , it was elected to perform an EBP because of persistent headaches that prevented the patient from ambulating. Informed consent was obtained from the parents. After inserting an $i v$ catheter, midazolam was administered in two boluses of $0.5 \mathrm{mg}$. The epidural space was identified with an 18-gauge Tuohy needle at the $\mathrm{L}_{4}-\mathrm{L}_{5}$ level using the loss of resistance technique with air and $10 \mathrm{ml}$ blood were drawn in a sterile fashion from the forearm. The blood was slowly injected through the epidural needle and, since no resistance was encountered, the entire volume was administered. Slight discomfort in the lower limbs was noted by the patient at the end of the procedure. After being kept supine for two hours, the patient was allowed to assume the erect position. The headache had completely resolved. In the following days, no further lower limb discomfort or headaches were noted.

\section{Discussion}

Postdural puncture headache is an uncommon complication of dural puncture in children. ${ }^{1,2}$ Given the number of diagnostic LPs performed in this age group, it seems that the paediatric population is less likely to experience PDPH although confinement of the patients to bed because of illness and failure of young children to report symptoms may result in underestimation of the true incidence of PDPH. In contrast to the needles used for $L P$, the epidural needle used in our patient was of a large bore. We are unaware of reports on the incidence of PDPH in children after an epidural technique.

Blaise et al. studied 30 patients ( 7 weeks-13 year old) prospectively undergoing minor abdominal or lower extremity surgery under spinal anaesthesia. ${ }^{1}$ A PDPH was observed in one patient in whom a 22-gauge spinal needle had been used. Subsequently, spinal blocks were performed with 24-gauge needles in children < nine years of age and with 22-gauge needles for older children. No additional cases of PDPH were observed. In paediatric oncology patients, eight PDPHs were observed after 36 diagnostic LPs performed with a 20 -gauge needle. ${ }^{2}$ Interestingly, in the 3-12 yr age group, only one PDPH 
was reported in a total of 27 dural punctures $(3.7 \%)$ while seven PDPHs occurred after nine LPs in children $>13$ yr of age. A possible explanation for the low incidence of PDPH within the paediatric population is the lower cerebrospinal fluid pressure in children. ${ }^{13,14}$ Furthermore, when assuming the erect position, the lower hydrostatic pressure in the lumbar area could result in less cerebrospinal fluid leakage in young patients.

Although no evidence of dural puncture was documented during the initial epidural technique in our patient, the clinical picture in this case was compatible with PDPH. It is possible that a small hole was made in the dura with the extremity of the Tuohy needle or with the tip of the epidural catheter without any cerebrospinal fluid leakage being noticed. The catheter's holes seemed to be correctly positioned in the epidural space since reinjection of local anaesthetics in the recovery room provided good analgesia without evidence of a spinal block. Severe radicular pain is reported rarely during or shortly after the injection of blood in the epidural space. ${ }^{15,16} \mathrm{An}$ terior displacement of nerve roots by blood extending into the intervertebral foramina has been shown by magnetic resonance imaging to occur soon after an EBP. ${ }^{17}$ Nerve root compression by an excessive volume of blood could go undetected in a patient under general anaesthesia. Since our patient was awake for the EBP, it was possible to evaluate the effect of the epidural injection clinically. In trying to prevent nerve root compression, it is our practice to stop the procedure when the patient complains of marked discomfort, pain or paraesthesia in the lower limbs or back. Since our patient was very cooperative, it was decided to perform the EBP under light sedation, with the help of an assistant reassuring the patient while helping her maintain an adequate position.

In two previous reports on the use of epidural blood patch in the paediatric population, 5 and $8 \mathrm{ml}$ of blood were given to children aged 9 and $12 \mathrm{yr}$ respectively. ${ }^{10,11}$ We are also aware of a case of a seven-year-old patient treated with EBP using $3 \mathrm{ml}^{12}$ In our patient, the volume of blood was injected slowly and the appearance of discomfort and/or pain was closely observed. The volume necessary to treat PDPH successfully in children is not known, although volumes of $15-20 \mathrm{ml}$ are suggested in adults. ${ }^{18}$ Szeinfeld et al. radiolabeled red blood cells being injected in the epidural space of adults and showed a mean spread of nine segments (range: 7-14) using 12-18 $\mathrm{ml}$ (average: $14.8 \mathrm{ml}$ ). ${ }^{19}$ Preferential cranial spread was demonstrated and authors advised doing the EBP as close as possible to the site of the dural puncture, either at the same or at a lower interspace. A volume of 12-15 $\mathrm{ml}$ was recommended based on the extension of blood in the epidural space, although the technique used to as- sess the spread of red blood cells gives a qualitative but not a quantitative evaluation of the volume of blood at each segment. No such studies have been performed in children.

Epidural opioids and local anaesthetics are becoming increasingly popular for the management of intra- and postoperative pain in children. ${ }^{20}$ Therefore, complications such as PDPH may be seen more often and additional information will become available regarding the incidence and treatment of PDPH in these patients. This case illustrates that EBP is an effective treatment for PDPH in children and that it can be performed in a conscious and cooperative child.

\section{References}

1 Blaise GA, Roy $W L$. Spinal anaesthesia for minor paediatric surgery. Can Anaesth Soc J 1986; 33: 227-30.

2 Bolder PM. Postlumbar puncture headache in pediatric oncology patients. Anesthesiology 1986; 65: 696-8.

3 Dittmann $M$, Renkl F. Spinal anesthesia with extremely fine needles (Letter). Anesthesiology 1989; 70: 1035-6.

4 Flaatten H, Rodt S, Rosland J, Vamnes J. Postoperative headache in young patients after spinal anaesthesia. Anaesthesia 1987 ; 42: 202-5.

5 Colonna-Romano P, Shapiro BE. Unintentional dural puncture and prophylactic epidural blood patch in obstetrics. Anesth Analg 1989; 69: 522-3.

6 Fernbach DJ. Headache after lumbar puncture (Letter). Lancet 1981; 2: 529.

7 Plaut TF. Lumbar puncture in children: its value and risk. Clin Pediatr 1968; 7: 130-3.

8 Gormley JB. Treatment of postspinal headache. Anesthesiology $1960 ; 21:$ 565-7.

9 Gielen $M$. Post dural puncture headache (PDPH): a review. Reg Anesth 1989; 4: 101-6.

10 Purtock RV, Buhl JL, Abram SE. Epidural blood patch in a nine-year-old boy. Reg Anesth 1984; 9: 154-5.

11 Ghia JN, Spielman FJ, Stieber SF. The diagnosis and successful treatment of post-lumbar puncture headache in a pediatric patient. Reg Anesth 1984; 9: 102-5.

12 Muñoz HL, Rufs JB, Dagnino JS, Bugedo GT, De La Fuente JB. Cefalea postpuncion lumbar: tratamiento con parche de sangre peridural en una paciente de 7 años. Rev Med Chil 1991; 119: 680-2.

13 DeJong $R N$, Magee $K R$. Lumbar puncture. In: DeJong RN (Ed.). The Neurologic Examination, 4th ed. New York: Harper \& Row, 1979: 750-64.

14 Welch $K$. The intracranial pressure in infants. J Neurosurg 1980; 52: 693-9.

15 Cornwall RD, Dolan WM. Radicular back pain following lumbar epidural blood patch. Anesthesiology 1975; 43 : 692-3.

16 Shantha TR, McWhirther WR, Dunbar RW. 
Complications following epidural "blood patch" for postlumbar-puncture headache. Anesth Analg 1973; 52: 67-72.

17 Beards SC, Jackson A, Griffiths AG, Horsman EL. Magnetic resonance imaging of extradural blood patches: appearances from $30 \mathrm{~min}$ to $18 \mathrm{~h}$. $\mathrm{Br} \mathrm{J}$ Anaesth 1993; 71 : 182-8.

18 Crawford JS. Epidural blood patch (Letter). Anaesthesia 1985; 40: 381.

19 Szeinfeld M, Ihmeidan IH, Moser MM, Machado $R$, Klose KJ, Serafini $A N$. Epidural blood patch: evaluation of the volume and spread of blood injected into the epidural space. Anesthesiology 1986; 64: 820-2.

20 Wood CE, Goresky GV, Klassen KA, Kuwahara B, Neil $S G$. Complications of continuous epidural infusions for postoperative analgesia in children. Can J Anaesth 1994; 41: 613-20. 